\title{
NOTA
}

\section{FITOTOXICIDADE DE TRÊS ANTIBIÓTICOS NA CULTURA IN VITRO DE ABACATEIRO $\left({ }^{1}\right)$}

\author{
LUIZ ANTONIO BIASI $\left(^{2,3}\right)$
}

\begin{abstract}
RESUMO
Desenvolveram-se dois experimentos para verificar o efeito do ácido nalidíxico, do cloranfenicol e da estreptomicina sobre a cultura in vitro do abacateiro 'Ouro Verde'. No primeiro, testou-se a influência de diversas concentraçōes $(0,12,5,25$, 50,100 e $200 \mathrm{mg} / \mathrm{L}$ ) desses antibióticos sobre a calogênese de discos foliares e, no segundo, o efeito sobre a brotação de gemas de segmentos nodais. Enquanto a formação de calos foi reduzida à metade com o uso de $50 \mathrm{mg} / \mathrm{L}$ de cloranfenicol, sua massa foi drasticamente reduzida já na concentração de $12,5 \mathrm{mg} / \mathrm{L}$. Restringiu-se o comprimento das brotações, adicionando os antibióticos ao meio de cultura, concluindo-se que os três foram tóxicos para o abacateiro, sendo recomendados apenas em casos de extrema necessidade, dependendo da suscetibilidade do microorganismo contaminante e da concentração necessária para seu controle.
\end{abstract}

Termos de indexação: antibióticos, abacateiro, Persea americana, fitotoxicidade, micropropagação.

\begin{abstract}
PHYTOTOXICITY OF THREE ANTIBIOTICS TO AVOCADO TISSUE CULTURE

Two experiments were carried out in order to verify the toxicity of nalidixic acid, chloramphenicol and streptomycin to avocado 'Ouro Verde' in vitro culture. In the first experiment, it was tested the effect of the antibiotics to callus initiation on leave explants, using a concentration range of $0,12.5,25,50,100$ and 200 $\mathrm{mg} / \mathrm{L}$. In the second experiment, sprouting from nodal segments were tested. The
\end{abstract}

( ${ }^{1}$ Recebido para publicaçăo em 14 de dezembro de 1994 e aceito em 11 de abril de 1995.

$\left({ }^{2}\right)$ Departamento de Horticultura, Escola Superior de Agricultura "Luiz de Queiroz"/USP. Caixa Postal 9, 13400-970 Piracicaba (SP).

$\left({ }^{3}\right)$ Com bolsa de pesquisa do CNPq. 
callus formation was reduced by $50 \%$ with $50 \mathrm{mg} / \mathrm{L}$ of chloramphenicol and the highest reduction in callus weight was observed with $12.5 \mathrm{mg} / \mathrm{L}$. The length of sprouts was reduced by incorporating antibiotics into plant growth medium. Results showed that the three antibiotics were toxic to avocado, and they must be used only in real necessity cases, depending on the bacterial susceptibility and the adequate concentration to control the contaminants.

Index terms: antibiotics, avocado, Persea americana, phytotoxicity, micropropagation.

A contaminação bacteriana é bastante nociva para os cultivos realizados in vitro, principalmente quando a infecção ocorre por bactérias latentes ou endógenas, introduzidas sistemicamente com os explantes (Fisse et al., 1987; Cassels et al., 1988).

Para o controle das bactérias, diversos autores citam a inclusão de antibióticos ao meio de cultura, entre eles: Wilson \& Power, 1989; Garcia \& Rafael, 1990; Barros \& Pasqual, 1991; Leifert et al., 1991.

Podem-se adicioná-los também ao meio de cultura por um período limitado, o necessário para a eliminação dos contaminantes (Kneifel \& Leonhardt, 1992; Leifert et al., 1992) ou utilizá-los na forma de imersão antes do isolamento (Tanaka et al., 1983; Scortichini \& Chiariotti, 1988).

Muitos antibióticos apresentam efeito fitotóxico para as plantas, alterando-lhes o crescimento in vitro (Dodds \& Roberts, 1985). Entretanto, essa influência sobre a regeneração vegetal depende da concentração à qual o tecido foi exposto (Okkels \& Pedersen, 1988).

Trabalhando com diversas espécies in vitro $\mathrm{e}$ quatro antibióticos, Leifert et al. (1992) definiram a seguinte ordem decrescente de fitotoxicidade: estreptomicina, polimixina, rifampicina e carbenicilina.

Os antibióticos do grupo dos aminoglicosídios, tais como estreptomicina, neomicina, kanamicina, gentamicina, amikacina e tobromacina, são tóxicos aos vegetais, mesmo em baixas concentrações (Pollock et al., 1983; Okkels \& Pedersen, 1988; Grattapaglia \& Machado, 1990), o que não se verifica com outros antibióticos, como os betalactamos (ampicilina e carbenicilina), as cefalosporinas (cefotaxime, cefaloridine, cefalotina), piperaciclina e rifampicina (Pollock et al., 1983; Okkels \& Pedersen, 1988; Poulsen, 1988; Leifert et al., 1992).

O objetivo deste trabalho foi verificar a fitotoxicidade de alguns antibióticos, utilizados no controle da contaminação bacteriana, na cultura in vitro do abacateiro 'Ouro Verde'.

\section{Material e Métodos}

Neste trabalho, desenvolvido no Laboratório de Biotecnologia do Departamento de Horticultura e Silvicultura da Faculdade de Agronomia da Universidade Federal do Rio Grande do Sul, utilizaram-se dois tipos de explantes, segmentos nodais e discos foliares coletados de mudas enxertadas do abacateiro 'Ouro Verde', mantidas em casa de vegetação.

Empregaram-se o ácido nalidíxico, o cloran-fenicol e a estreptomicina, selecionando os dois primeiros pela sua eficiência no controle de um contaminante específico em abacateiro (Biasi, 1993) e o último, para comparação, devido a sua toxicidade já verificada em outras culturas.

Para a assepsia, lavaram-se as folhas e as brotações em água corrente, desinfestando-as, depois, pela imersão em álcool $70 \%$ por um minuto, seguida de imersão em hipoclorito de sódio $1 \%$ por dez minutos e três lavagens em água deionizada e autoclavada (Biasi et al., 1994).

Os discos foliares com $0,5 \mathrm{~cm}^{2}$ foram retirados da parte basal e nervura central das folhas, por meio de um vazador. Com os discos foliares, instalou-se um experimento com delineamento inteiramente casualizado em esquema fatorial $(3 \times 6)$ com cinco repetições e dois frascos por parcela. Cada frasco, incubado no escuro, a $25^{\circ} \mathrm{C}$, por 60 
dias, recebeu três explantes. Os tratamentos resultaram da utilização dos três antibióticos: ácido nalidíxico, cloranfenicol e estreptomicina em seis concentrações: $0,12,5,25,50,100$ e $200 \mathrm{mg} / \mathrm{L}$.

Com os segmentos nodais, instalou-se outro experimento com delineamento inteiramente casualizado, com sete tratamentos, quinze repetições e dois frascos por parcela. Cada frasco, com quatro explantes, foi incubado à luz, a $25^{\circ} \mathrm{C}$, por 53 dias.

Os tratamentos foram os seguintes:

1) Testemunha;

2) Ácido nalidíxico $(50 \mathrm{mg} / \mathrm{L})$;

3) Cloranfenicol $(50 \mathrm{mg} / \mathrm{L})$;

4) Estreptomicina (50 $\mathrm{mg} / \mathrm{L})$;

5) Ácido nalidíxico $(25 \mathrm{mg} / \mathrm{L})+$ cloranfenicol (25 $\mathrm{mg} / \mathrm{L})$;

6) Ácido nalidíxico $(25 \mathrm{mg} / \mathrm{L})+$ estreptomicina (25 $\mathrm{mg} / \mathrm{L})$;

7) Cloranfenicol (25 mg/L) + estreptomicina (25 $\mathrm{mg} / \mathrm{L})$.

Em ambos os experimentos, o meio de cultura utilizado foi o MS (Murashige \& Skoog, 1962) solidificado com $7 \mathrm{~g} / \mathrm{L}$ de ágar e os frascos, com $200 \mathrm{~mL}$ de capacidade, receberam $30 \mathrm{~mL}$ de meio.
No experimento com os discos foliares, adicionaram-se $10 \mathrm{mg} / \mathrm{L}$ de ácido indolbutírico (AIB) e $1 \mathrm{mg} / \mathrm{L}$ de 6-benzilaminopurina (BAP) ao meio de cultura; com os segmentos nodais, somaram-se 3 $\mathrm{mg} / \mathrm{L} \mathrm{dc} \mathrm{BAP,} \mathrm{conforme} \mathrm{Biasi} \mathrm{(1993).} \mathrm{Esteriliza-}$ ram-se os antibióticos a frio, por meio de filtros de membrana ("millipore"), com $0,45 \mu \mathrm{m}$ de diâmetro, adicionando-os ao meio de cultura, quando em resfriamento.

Para se proceder à análise da variância, os dados de massa dos calos foram transformados em $(\mathrm{X}+1)^{1 / 2}$, pois verificou-se, pelo teste de Bartlet, que as variâncias dos tratamentos não eram homogêneas. Realizou-se a comparação entre os tratamentos pelo teste de Tukey para todas as variáveis, efetuando-se também a análise de regressão para as variáveis do experimento com discos foliares.

\section{Resultados e Discussão}

Houve interação significativa entre os antibióticos e concentrações utilizadas no experimento com discos foliares (Quadro 1). As análises de regressão entre as concentrações de cada antibiótico e as variáveis porcentagem de calogênese e massa dos calos, apresentaram, porém, significância apenas em graus muito elevados, com baixo coeficiente de determinação. Por isso, encontram-se, no quadro 3 , apenas as médias dos tratamentos comparadas pelo teste de Tukey.

Quadro 1. Resumo da análise da variância do efeito dos antibióticos e concentrações sobre a calogênese de discos foliares de abacateiro 'Ouro Verde' cultivados em meio de cultura MS por 60 dias

GL

$\mathrm{QM}$

\begin{tabular}{lccc}
\cline { 3 - 3 } & & Calo & Massa \\
\hline Antibiótico & 2 & $\%$ & $\mathrm{mg}$ \\
Concentração & 5 & $7.958,03^{* * *}$ & $543,01^{* * *}$ \\
Antib. x Concent. & 10 & $18.240,26^{* * *}$ & $781,86^{* * *}$ \\
Resíduo & 72 & $2.949,15 * * *$ & $68,29 * * *$ \\
Total & 89 & 38,74 & 14,38 \\
\hline
\end{tabular}


O cloranfenicol revelou maior efeito fitotóxico do que os demais antibióticos, reduzindo significativamente a formação de calos já na concentração de $50 \mathrm{mg} / \mathrm{L}$ e, com o uso de $100 \mathrm{mg} / \mathrm{L}$, a calogênese foi nula, o que apenas aconteceu com a dose de $200 \mathrm{mg} / \mathrm{L}$ de estreptomicina. Já com o ácido nalidíxico, mesmo com o uso desta concentração, ainda houve a formação de calos em 33,2\% dos explantes (Quadro 3). Phillips et al. (1981), trabalhando com explantes de Helianthus tuberosus, observaram uma redução no crescimento pela presença de $50 \mathrm{mg} / \mathrm{L}$ de cloranfenicol no meio de cul- tura, o que não foi verificado com a mesma concentração de ácido nalidíxico.

O efeito tóxico do cloranfenicol é mais evidente quando se observa a massa média dos calos, que, já na concentração de $12,5 \mathrm{mg} / \mathrm{L}$, foi drasticamente reduzida em relação à testemunha e aos outros antibióticos na mesma concentração (Quadro 3). Okkels \& Pedersen (1988) também verificaram efeito tóxico do cloranfenicol sobre a cultura de tecidos de beterraba e cenoura nas concentraçōes de $8 \mathrm{e}$ $25 \mathrm{mg} / \mathrm{L}$ respectivamente.

Quadro 2. Resumo da análise da variância do efeito dos antibióticos sobre a brotação de segmentos nodais de abacateiro 'Ouro Verde' cultivados por 53 dias em meio de cultura MS

Causas de variação

GL

QM

Gemas brotadas

Comprimento

$\%$

$\mathrm{mm}$

\begin{tabular}{lrcc} 
Antibiótico & 6 & $657,96 \mathrm{~ns}$ & $48,27 * * *$ \\
Resíduo & 98 & 419,75 & 4,95 \\
Total & 104 & - & - \\
\hline
\end{tabular}

*** Significância estatística ao nível de $0,1 \%$. ns: não significativo.

Quadro 3. Porcentagem de explantes calejados e massa média dos calos de discos foliares do abacateiro 'Ouro Verde' cultivados em meio de cultura MS por 60 dias com ácido nalidíxico (A), cloranfenicol (C) e estreptomicina (E)

\begin{tabular}{|c|c|c|c|c|c|c|}
\hline \multirow{2}{*}{ Concentração } & \multicolumn{3}{|c|}{ Calo } & \multicolumn{3}{|c|}{ Massa } \\
\hline & A & $\mathrm{C}$ & $\mathrm{E}$ & $\mathrm{A}$ & $\mathrm{C}$ & $\mathrm{E}$ \\
\hline $\mathrm{mg} / \mathrm{L}$ & 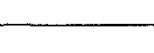 & $-\%$ & - & - & $-\mathrm{mg}$ & 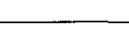 \\
\hline 0 & $100 \mathrm{Aa}$ & $100 \mathrm{Aa}$ & $100 \mathrm{Aa}$ & $557 \mathrm{Aab}$ & $530 \mathrm{Aa}$ & $555 \mathrm{Aa}$ \\
\hline 12,5 & $100 \mathrm{Aa}$ & $100 \mathrm{Aa}$ & $100 \mathrm{Aa}$ & $669 \mathrm{Aa}$ & $51 \mathrm{Bbc}$ & $464 \mathrm{Aa}$ \\
\hline 25 & $100 \mathrm{Aa}$ & $100 \mathrm{Aa}$ & $100 \mathrm{Aa}$ & $343 \mathrm{Abc}$ & $75 \mathrm{Bb}$ & $383 \mathrm{Aa}$ \\
\hline 50 & $100 \mathrm{Aa}$ & $49,8 \mathrm{Bb}$ & $100 \mathrm{Aa}$ & $154 \mathrm{Acd}$ & $43 \mathrm{Bbc}$ & $136 \mathrm{ABb}$ \\
\hline 100 & $100 \mathrm{Aa}$ & $O B C$ & $100 \mathrm{Aa}$ & $94 \mathrm{Ad}$ & $\mathrm{OBc}$ & $103 \mathrm{Ab}$ \\
\hline 200 & $33,2 \mathrm{Ab}$ & $\mathrm{OBC}$ & $\mathrm{OBb}$ & $44 \mathrm{Ad}$ & $0 \mathrm{Ac}$ & $O A c$ \\
\hline C.V. (\%) & & 8,1 & & & 30,0 & \\
\hline
\end{tabular}

Médias seguidas pela mesma letra, maiúscula na linha e minúscula na coluna, não diferem significativamente pelo teste de Tukey a $5 \%$ de probabilidade. 
Quadro 4. Porcentagem de gemas brotadas e comprimento das brotaçōes de segmentos nodais do abacateiro 'Ouro Verde' cultivados por 53 dias em meio de cultura MS com ácido nalidíxico, cloranfenicol e estreptomicina

Tratamentos

Gemas brotadas

Comprimento

\begin{tabular}{llc}
\hline & $\%$ & $\mathrm{~mm}$ \\
Testemunha & $93,7 \mathrm{a}$ & $13,9 \mathrm{a}$ \\
Estreptomicina $(50 \mathrm{mg} / \mathrm{L})$ & $82,3 \mathrm{a}$ & $10,9 \mathrm{ab}$ \\
Cloranfenicol $(50 \mathrm{mg} / \mathrm{L})$ & $77,4 \mathrm{a}$ & $10,5 \mathrm{~b}$ \\
Cloranfenicol $(25 \mathrm{mg} / \mathrm{L})+$ estreptomicina $(25 \mathrm{mg} / \mathrm{L})$ & $95,3 \mathrm{a}$ & $10,4 \mathrm{~b}$ \\
Ácido nalidíxico $(50 \mathrm{mg} / \mathrm{L})$ & $88,5 \mathrm{a}$ & $9,9 \mathrm{~b}$ \\
Cloranfenicol $(25 \mathrm{mgL})+$ ácido nalidíxico $(25 \mathrm{mg} / \mathrm{L})$ & $87,5 \mathrm{a}$ & $8,3 \mathrm{~b}$ \\
Estreptomicina $(25 \mathrm{mg} / \mathrm{L})+$ ácido nalidíxico $(25 \mathrm{mg} / \mathrm{L})$ & $90,3 \mathrm{a}$ & $7,9 \mathrm{~b}$ \\
C.V. $(\%)$ & 24,0 & 29,9 \\
\hline
\end{tabular}

Médias seguidas pela mesma letra não diferem significativamente pelo teste de Tukey a $5 \%$ de probabilidade.

A ação do ácido nalidíxico e da estreptomicina foi muito semelhante quanto à massa dos calos, não diferindo estatisticamente em nenhuma concentração utilizada (Quadro 3).

No experimento com os segmentos nodais, não se verificou influência estatística significativa dos antibióticos para a porcentagem de gemas brotadas, mas, sim, para o comprimento das brotações (Quadro 2).

Todos os tratamentos provocaram uma redução do crescimento das brotações em relação à testemunha, não diferindo entre si (Quadro 4), fato semelhante ao observado por Biasi (1993) para o mesmo cultivar de abacateiro, com os antibióticos ácido nalidíxico e cloranfenicol. Pollock et al. (1983) também verificaram efeito tóxico desses antibióticos, na cultura de células da Nicotiana plumbaginifolia, apresentando o cloranfenicol efeito inibitório já na concentração de $1 \mathrm{mg} / \mathrm{L}$.

A fitotoxicidade dos antibióticos depende da concentração à qual o tecido foi exposto e da tolerância da espécie tratada, conforme Okkels \& Pedersen (1988). Esses autores verificaram que a concentração de cloranfenicol para inibir $50 \%$ da regeneração, na cultura de beterraba e cenoura in vitro, foi bem inferior à concentração de estrepto- micina, e que a cenoura apresentou maior tolerância aos antibióticos do que a beterraba.

Esses fatos também foram obervados em outras culturas por Scortichini \& Chiariotti (1988), Wilson \& Power (1989), Fiola et al. (1990), Mathews \& Litz (1990), Leifert et al. (1991, 1992). Entretanto, para algumas espécies em determinadas formas de regeneração in vitro, certos antibióticos podem até mesmo estimular a proliferação e diferenciação celular, como verificado em cenoura (Chang \& Schmidt, 1991) e painço (Eapen \& George, 1990).

\section{Conclusão}

Os três antibióticos testados apresentaram efeito tóxico para o abacateiro, sendo recomendados apenas em casos de extrema necessidade, dependendo da suscetibilidade do microorganismo contaminante e da concentração necessária para seu controle.

\section{REFERÊNCIAS BIBLIOGRÁFICAS}

BARROS, I. de \& PASQUAL, M. Contaminação fúngica, bacteriana e oxidação "in vitro" de explantes de Coffea arabica L. cv. Catuaí LCH-2077-2-5-44. Ciência e Prática, Lavras, 15(2):145-153, 1991. 
BIASI, L.A. Micropropagação do abacateiro 'Ouro Verde' através da cultura de segmentos nodais $e$ calogênese a partir de discos foliares. Porto Alegre, 1993. 163p. Dissertação (Mestrado em Fitotecnia) - UFRGS, 1993.

BIASI, L.A.; KOLLER, O.C. \& KÄMPF, A.N. Micropropagação do abacateiro 'Ouro Verde' a partir de segmentos nodais. Pesquisa Agropecuária Brasileira, Brasília, 29(7):1051-1058, 1994.

CASSElS, A.C.; CARNEY, B.F.; McCARTHY, E.; McHUGH, A. \& HARMEY, M.A. Problems posed by cultivable bacterial endophytes in the establishment of axenic cultures of Pelargonium $x$ domesticum: the use of Xanthomonas pelargonii - specific ELISA, DNA probes and culture indexing in the screening of antibiotic treated and untreated donor plants. Acta Horticulturae, Wageningen, (225):153-161, 1988.

CHANG, C.C. \& SCHMIDT, D.R. Initiation and proliferation of carrot callus using a combination of antibiotics. Planta, New York, 185:523-526, 1991.

DODDS, J.H. \& ROBERTS, L.W. Experiments in plant tissue culture. 2.ed. Cambridge, Cambridge University Press, 1985. 232p.

EAPEN, S. \& GEORGE, L. Influence of phytohormones, carbohydrates, aminoacids, growth supplements and antibiotics on somatic embryogenesis and plant differentiation in finger millet. Plant Cell, Tissue and Organ Culture, Dordrecht, 22:87-93, 1990.

FIOLA, J.A.; HASSAN, M.A.; SWARTZ, H.J.; BORS, R.H. \& McNICOLS, R. Effect of thidiazuron, ligth fluence rates and kanamycin on in vitro shoot organogenesis form excised Rubus cotyledons and leaves. Plant Cell, Tissue and Organ Culture, Dordrecht, 20:223-228, 1990.

FISSE, J.; BATALLE, A. \& PERA, J. Endogenous bacteria elimination in ornamental plants. Acta Horticulturae, Wageningen, (212):87-90, 1987.

GARCIA, E.G. de \& RAFAEL, M. Control de ta oxidación y contaminación en microesquejes de café (Coffea arabica 'Catimor') cultivados "in vitro". Agronomia Tropical, Maracay, 40(4-6):281-290, 1990.

GRATTAPAGLIA, D. \& MACHADO, M.A. Micropropagação. In: TORRES, A.C. \& CALDAS, L.S., eds. Técnicas e aplicações da cultura de tecidos de plantas. Brasília, ABCTP, EMBRAPA-CNPH, 1990. p.99-169.

KNEIFEL, W. \& LEONHARDT, W. Testing of different antibiotics against gram-positive and gram-negative bacteria isolated from plant tissue culture. Plant Cell, Tissue and Organ Culture, Dordrecht, 29:139-144, 1992.
LEIFERT, C.; CAMOTTA, H. \& WAITES, W.M. Effect of combinations of antibiotics on micropropagated Clematis, Delphinium, Hosta, Iris and Photinia. Plant Cell, Tissue and Organ Culture, Dordrecht, 29:153-160, 1992.

LEIFERT, C.; CAMOTTA, H.; WRIGHT, S.M.; WAITES, B.; CHEYNE, V.A. \& WAITES, W.M. Elimination of Lactobacillus plantarum, Corynebacterium spp., Staphylococcus saprophyticus and Pseudomonas paucimobilis from micropropagated Hemerocallis, Chisya and Delphinium cultures using antibiotics. Journal of Applied Bacteriology, Oxford, 71(4):307-330, 1991.

MATHEWS, H. \& LITZ, R. E. Kanamycin sensitivity of mango somatic embryos. HortScience, Alexandria, 25(8):965-966, 1990.

MURASHIGE, T. \& SKOOG, F. A revised medium for rapid growth and bioassays with tobacco tissue cultures. Physiologia Plantarum, Copenhagen, 15:473497, 1962.

OKKELS, F.T. \& PEDERSEN, M.G. The toxicity to plant tissue and to Agrobacterium tumefaciens of some antibiotics. Acta Horticulturae, Wageningen, (225):199-207, 1988

PHILLIPS, R.; ARNOTT, S.M. \& KAPLAN, S.E. Antibiotics in plant tissue culture: rifampicin effectively controls bacterial contaminants without affecting the growth of short-term explant cultures of Helianthus tuberosus. Plant Science Letters, Amsterdam, 21:235-240, 1981.

POLLOCK, K.; BARFIELD, D.G. \& SHIELDS, R. The toxicity of antibiotics to plant cell cultures. Plant Cell Reports, Berlin, 2:36-39, 1983.

POULSEN, G.B. Elimination of contaminating microorganisms from meristem culture of apple rootstock M26. Acta Horticulturae, Wageningen, (225):193197, 1988.

SCORTICHINI, M. \& CHIARIOTTI, A. In vitro culture of Prunus persica var. Laevis Gray (nectarine): detection of bacterial contaminants and possibility of decontamination by means of antibiotics. Acta Horticulturae, Wageningen, (225):109-118, 1988.

TANAKA, M.; KUMURA, M. \& GOI, M. Surface-sterilization for in vitro culture of phalacnopsis flowerstalk cutting using antimicrobials. Acta Horticulturae, Wageningen, (131):321-328, 1983.

WILSON, Z.A. \& POWER, J.B. Elimination of systemic contamination in explant and protoplast cultures of rubber (Hevea brasiliensis Muell. Arg.). Plant Cell Reports, Berlin, 7:622-625, 1989. 